\title{
Water requirement of Paddy under Different Land Levelling, Cultivation Practices and Irrigation Methods
}

\author{
Ravindra Yaligar*, P. Balakrishnan, U. Satishkumar, P. S. Kanannavar, \\ A. S. Halepyati, M. L. Jat and N. L. Rajesh \\ Department of Soil and Water Engineering, College of Agricultural Engineering, University of \\ Agricultural Sciences (UAS) Raichur, Karnataka, India \\ *Corresponding author
}

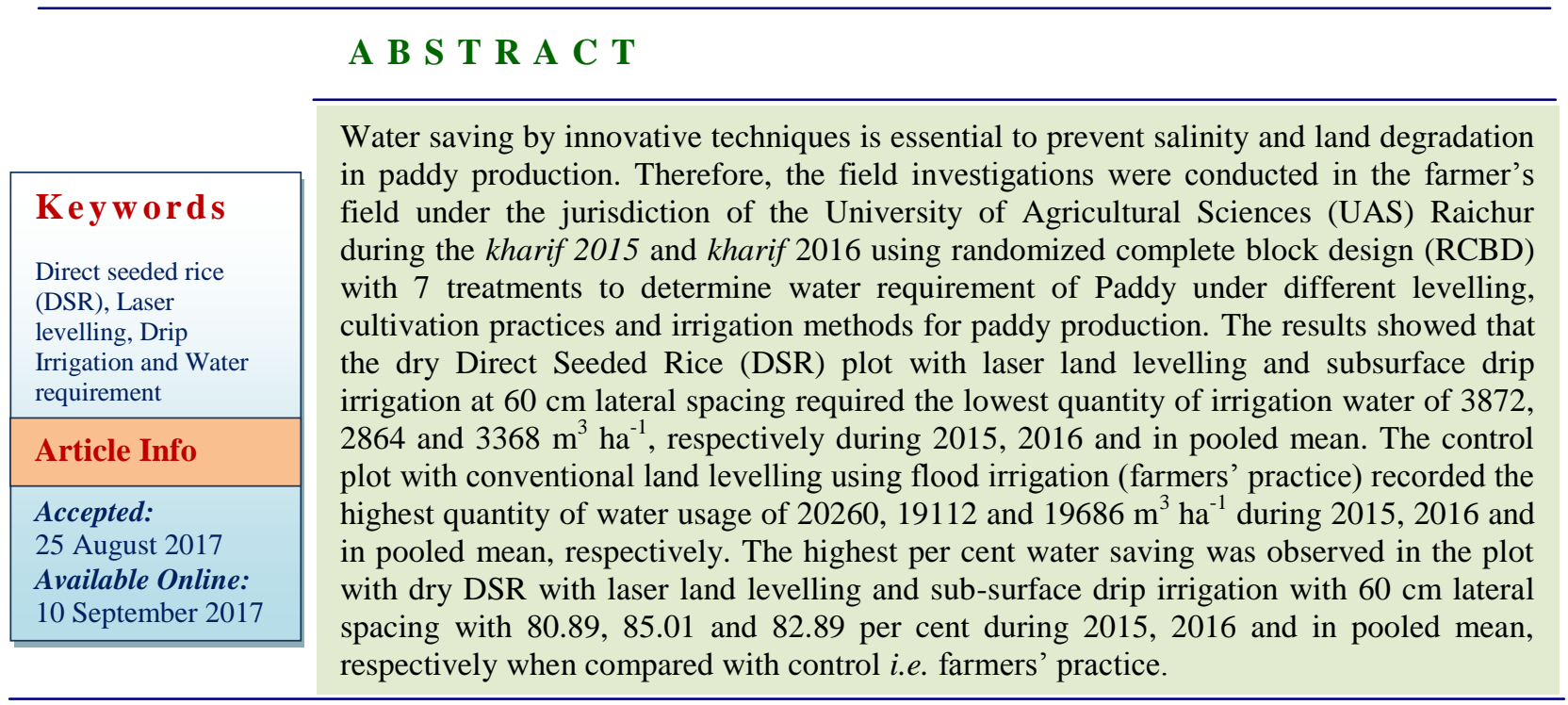

\section{Introduction}

Rice (Oryza sativa L.) is the staple food of more than half of the population of the world and its production is an important target to provide food security and livelihood for millions. The world's total estimated area under rice production is $159 \mathrm{M}$ ha with a production of $670 \mathrm{M}$ t with an average yield of 3,889 $\mathrm{kg}$ per ha (Anon., 2011). India ranks second in rice production, as it is grown in almost all the states of the country. In India, rice is cultivated in a wide range of ecosystems viz., irrigated (21 M ha), rainfed lowlands (14 M ha), rainfed uplands (6 M ha) and flood prone ( $3 \mathrm{M}$ ha). The most common method that is being followed by the farmers is generally transplanting, while dry seeding or wet seeding method for cultivation of rice is also adopted depending upon the situation. India faces the challenge of meeting the future demand of food grains due to diversion of land and water resources to not only agriculture but also to other sectors of economy. With the current estimates, India would need 37 per cent more rice and wheat 
by 2025 with 9 to 10 per cent less water available for irrigation compared to the year 2000. The total area under rice in Karnataka is $1.33 \mathrm{M}$ ha with an annual production of 3.54 $\mathrm{Mt}$ and with a productivity of 2,670 $\mathrm{kg}$ per ha (Anon., 2016). It is cultivated in the command areas of Cauvery basin in south, Tungabhadra and Upper Krishna projects in north where transplanting with flood irrigation is the major method of cultivation. The traditional irrigation method like flooding water in paddy fields consumes more water leading to wastage of precious water resources and the least water productivity. Imminent water crisis due to increasing demands from various sectors, water-demanding nature of traditionally cultivated rice and climbing labour costs all call for search of alternative management methods to increase water productivity, system sustainability and profitability in rice. With this in mind the field investigations were conducted on water requirement of paddy with innovative techniques of laser land levelling and drip irrigation methods for paddy production were taken up in the farmer's field.

\section{Materials and Methods}

The experiment was carried out in farmer's field located at Govinadoddi village in Manvi taluka of Raichur district under during kharif 2015 and kharif 2016 using randomized complete block design with 7 treatments which were replicated thrice. The treatments included the land levelling methods viz., laser levelling with near table top level or zero per cent slope and conventional levelling, cultivation practices viz., transplanted rice (TPR) and direct seeded rice (DSR) and irrigation methods viz., drip and flood irrigation. The treatments included the land levelling methods viz., laser levelling with near table top level or zero per cent slope and conventional levelling, cultivation practices viz., transplanted rice (TPR) and direct seeded rice (DSR) and irrigation methods viz., drip and flood irrigation. The treatments were viz., $\mathrm{T}_{1}$ - Dry direct seeded rice (DSR) with laser land levelling and surface drip irrigation with $80 \mathrm{~cm}$ lateral spacing, $\mathrm{T}_{2}$ - Dry direct seeded rice with laser land levelling and surface drip irrigation with $60 \mathrm{~cm}$ lateral spacing, $\mathrm{T}_{3}$ - Dry direct seeded rice with laser land levelling and subsurface drip irrigation with $60 \mathrm{~cm}$ lateral spacing, $\mathrm{T}_{4}$ - Dry direct seeded rice with laser land levelling and subsurface drip irrigation with $80 \mathrm{~cm}$ lateral spacing, $\mathrm{T}_{5}$ - Transplanted rice (TPR) with laser land levelling and conventional method of flood irrigation, $\mathrm{T}_{6}-$ Dry direct seeded rice with conventional land levelling and conventional method of flood irrigation and $\mathrm{T}_{7}$ - Control (transplanted rice with conventional land levelling using flood irrigation) i.e., farmer's practice. The test crop used was paddy with variety BPT - 5204 (145-150 days duration). The Diagram showing schematic chart of precise laser land levelling concept is given in Fig.1. Fig.2. shows drip irrigation system with treatments installed in farmers field.

The scheduling of drip irrigation was done based on daily PE values during the crop growth period and the duration of irrigation was computed as follows:

Irrigation hours $(\mathrm{h})=-\mathrm{ET}_{\mathrm{c}}(\mathrm{mm})$
Application rate $\left(\mathrm{mm} \mathrm{h}^{-1}\right)$

Whereas,

Actual evaporation or crop evapotranspiration $\left(\mathrm{ET}_{\mathrm{c}}\right)$ in $\mathrm{mm}=\mathrm{ET}_{0} \times$ Crop factor

Reference evaporation or evapotranspiration $\left(\mathrm{ET}_{0}\right)$ in $\mathrm{mm}=$ Previous day evaporation $\mathrm{x}$ Pan factor.

Crop factors for paddy at its initial, crop development, reproductive and maturity 
stages is used were $1.15,1.23,1.14$ and 1.02 respectively and constant pan factor of 0.7 was used. Application rate with discharge of 2 Lph@1.5 kg cm${ }^{-2}$ was calculated using Eq. 2 .

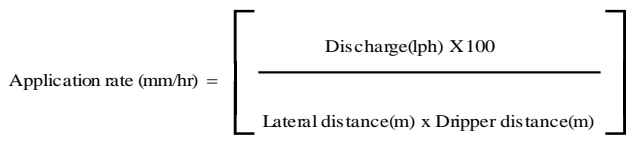

(Eq. 2)

Two lateral spacings of $0.6 \mathrm{~m}$ and $0.8 \mathrm{~m}$ were used in the study with a constant dripper distance of $0.4 \mathrm{~m}$ throughout the experiment.

\section{Results and Discussion}

For the field investigations, the data regarding irrigation water used $\left(\mathrm{m}^{3} \mathrm{ha}^{-1}\right)$ and per cent water saving as influenced by different land levelling (Laser and Conventional), cultivation practices (DSR and TPR) and irrigation (Drip and Flood) methods for paddy production are presented in Table 1.

It was observed that the treatment $\mathrm{T}_{3}$ required the lowest quantity of irrigation water of 3872, 2864 and $3368 \mathrm{~m}^{3} \mathrm{ha}^{-1}$ during 2015, 2016 and in pooled mean, respectively followed the treatment $\mathrm{T}_{2}(3918,2928$ and $\left.3423 \mathrm{~m}^{3} \mathrm{ha}^{-1}\right), \mathrm{T}_{4}\left(4034,3061\right.$ and $3548 \mathrm{~m}^{3}$ $\mathrm{ha}^{-1}$ ) and $\mathrm{T}_{1}$ which recorded water usage of 4260, 3142 and $3701 \mathrm{~m}^{3} \mathrm{ha}^{-1}$ during 2015, 2016 and in pooled mean, respectively. The control plot with farmers' practice $\left(T_{7}\right)$ recorded the highest quantity of water usage of 20260, 19112 and $19686 \mathrm{~m}^{3} \mathrm{ha}^{-1}$ during 2015, 2016 and in pooled mean, respectively. It was followed by $\mathrm{T}_{5}(17260,16065$ and $\left.16663 \mathrm{~m}^{3} \mathrm{ha}^{-1}\right)$ and $\mathrm{T}_{6}$ (11680, 10662 and $11171 \mathrm{~m}^{3} \mathrm{ha}^{-1}$ ).

From the pooled mean the highest per cent water saving was observed in the treatment $T_{3}$ (82.89 per cent) when compared with control (conventional land levelling with flood irrigation) i.e. farmers' practice $\left(\mathrm{T}_{7}\right)$. It was followed by $\mathrm{T}_{2}$ (82.61 per cent), $\mathrm{T}_{4}$ with 81.98 and $\mathrm{T}_{1}$ (81.20 per cent). Dry DSR with conventional land levelling and conventional method of flood irrigation $\left(\mathrm{T}_{6}\right)$ recorded 43.25 per cent water saving followed by TPR with laser land levelling and conventional method of flood irrigation $\left(\mathrm{T}_{5}\right)$ with 15.36 per cent water saving when compared to farmers' practice.

The similar trend was noticed with the depth of irrigation water applied during 2015, 2016 and pooled mean. From Table 1 and Fig. 3 (a) and (b) considering the effective rainfall during crop period, the quantity of irrigation water applied for paddy was the least in $T_{3}$ $(33.68 \mathrm{~cm})$.

It was followed by $\mathrm{T}_{2}$ with $34.23 \mathrm{~cm}, \mathrm{~T}_{4}$ with $35.48 \mathrm{~cm}$ and $\mathrm{T}_{1}$ with $37.01 \mathrm{~cm}$. The water requirement was the highest in $\mathrm{T}_{7}$ (196.86 $\mathrm{cm})$. It was followed by $\mathrm{T}_{5}(166.63 \mathrm{~cm})$ and $\mathrm{T}_{6}$ $(111.71 \mathrm{~cm})$. Significant difference was observed in depth of water requirement of paddy as influenced by different cultivation practices, land levelling and irrigation methods.

Among sown rice, the pooled effective rainfall during the crop period, the total quantity of water requirement of paddy was lowest in $\mathrm{T}_{3}(66.65 \mathrm{~cm})$ followed by 67.20 , 68.44 and $69.98 \mathrm{~cm}$, respectively in $\mathrm{T}_{2}, \mathrm{~T}_{4}$ and $\mathrm{T}_{1}$. The total water requirement was the highest in $\mathrm{T}_{6}(144.68 \mathrm{~cm})$. In transplanted rice the water requirement in $\mathrm{T}_{5}(199.59 \mathrm{~cm})$ was lesser than $\mathrm{T}_{7}(229.83 \mathrm{~cm})$.

Among sown rice, the pooled depth of irrigation water requirement was higher in $\mathrm{T}_{6}$ $(111.71 \mathrm{~cm})$. It was followed by $\mathrm{T}_{1}(37.01$ $\mathrm{cm}), \mathrm{T}_{4}(35.48 \mathrm{~cm})$ and $\mathrm{T}_{2}(34.23 \mathrm{~cm})$ respectively. The least was recorded in $T_{3}$ $(33.68 \mathrm{~cm})$. Treatment $\mathrm{T}_{5}$ recorded total water requirement of $166.63 \mathrm{~cm}$ followed by $\mathrm{T}_{7}$ $(196.86 \mathrm{~cm})$. 
Table.1 Quantity of irrigation water applied and per cent saving as influenced by different cultivation practices, land levelling and irrigation methods for paddy production

\begin{tabular}{|c|c|c|c|c|c|c|c|c|c|c|c|c|}
\hline \multirow{2}{*}{ Treatment } & \multicolumn{3}{|c|}{$\begin{array}{l}\text { Total depth of irrigation } \\
\text { water applied }(\mathrm{cm})\end{array}$} & \multicolumn{3}{|c|}{$\begin{array}{l}\text { Total quantity of irrigation } \\
\text { water applied }\left(\mathrm{m}^{3} \mathrm{ha}^{-1}\right)\end{array}$} & \multicolumn{3}{|c|}{$\begin{array}{l}\text { Quantity of irrigation water } \\
\text { saved over control } \\
\left(\mathrm{T}_{7}\right)\left(\mathbf{m}^{\mathbf{3}} \mathbf{h a}^{-1}\right)\end{array}$} & \multicolumn{3}{|c|}{$\begin{array}{l}\text { Per cent of irrigation water } \\
\text { saved over control }\left(\mathbf{T}_{7}\right)\end{array}$} \\
\hline & 2015 & 2016 & Pooled & 2015 & 2016 & Pooled & 2015 & 2016 & Pooled & 2015 & 2016 & Pooled \\
\hline $\mathrm{T}_{1}$ & 42.6 & 31.42 & 37.01 & 4260 & 3142 & 3701 & 16000 & 15970 & 15985 & 78.97 & 83.56 & 81.20 \\
\hline $\mathrm{T}_{2}$ & 39.18 & 29.28 & 34.23 & 3918 & 2928 & 3423 & 16342 & 16184 & 16263 & 80.66 & 84.68 & 82.61 \\
\hline $\mathrm{T}_{3}$ & 38.72 & 28.64 & 33.68 & 3872 & 2864 & 3368 & 16388 & 16248 & 16318 & 80.89 & 85.01 & 82.89 \\
\hline $\mathrm{T}_{4}$ & 40.34 & 30.61 & 35.48 & 4034 & 3061 & 3548 & 16226 & 16051 & 16139 & 80.09 & 83.98 & 81.98 \\
\hline $\mathrm{T}_{5}$ & 172.6 & 160.65 & 166.63 & 17260 & 16065 & 16663 & 3000 & 3047 & 3024 & 14.81 & 15.94 & 15.36 \\
\hline $\mathrm{T}_{6}$ & 116.8 & 106.62 & 111.71 & 11680 & 10662 & 11171 & 8580 & 8450 & 8515 & 42.35 & 44.21 & 43.25 \\
\hline $\mathrm{T}_{7}$ & 202.6 & 191.12 & 196.86 & 20260 & 19112 & 19686 & --- & --- & -- & --- & --- & --- \\
\hline
\end{tabular}

$\mathrm{T}_{1}$ - Dry Direct Seeded Rice (DSR) with Laser land levelling and Surface Drip irrigation ( $80 \mathrm{~cm}$ Lateral spacing)

$\mathrm{T}_{2}$ - Dry Direct Seeded Rice (DSR) with Laser land levelling and Surface Drip irrigation (60 cm Lateral spacing)

$\mathrm{T}_{3}$ - Dry Direct Seeded Rice (DSR) with Laser land levelling and Sub-surface Drip irrigation $(60 \mathrm{~cm}$ Lateral spacing)

$\mathrm{T}_{4}$ - Dry Direct Seeded Rice (DSR) with Laser land levelling and Sub-surface Drip irrigation (80 cm Lateral spacing)

$\mathrm{T}_{5}$ - Transplanted Rice (TPR) with Laser land levelling and Conventional method of flood irrigation

$\mathrm{T}_{6}$ - Dry Direct Seeded Rice (DSR) with Conventional land levelling and Conventional method of flood irrigation

$\mathrm{T}_{7}$ - Control (Conventional land levelling with Conventional method flood irrigation) i.e. Farmers' Practice 
Fig.1 Schematic chart of laser land levelling concept

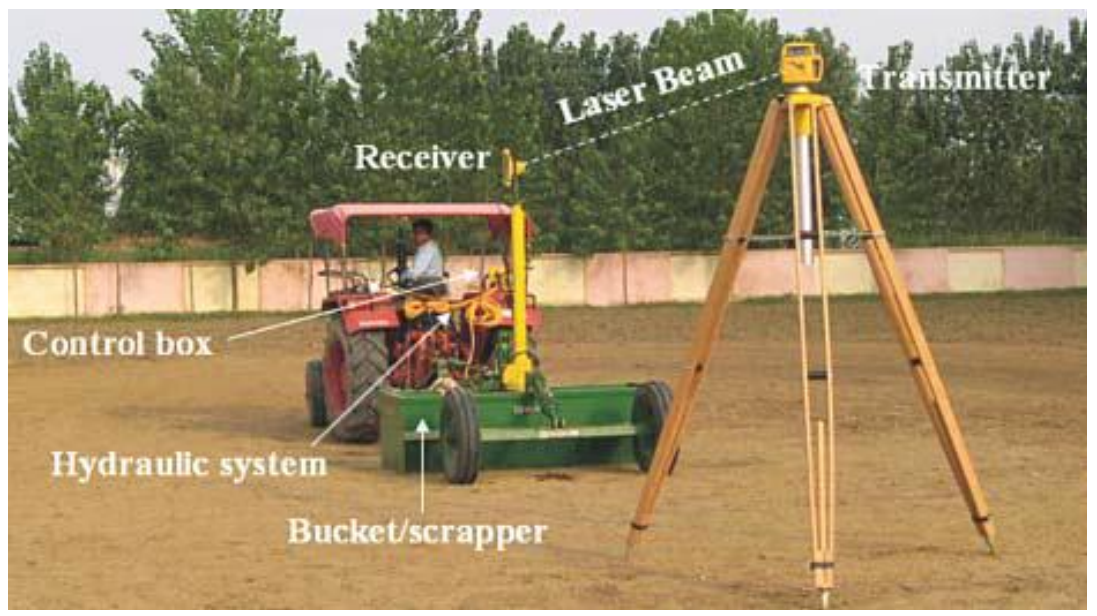

Fig.2 Drip irrigation system installed in farmer's field
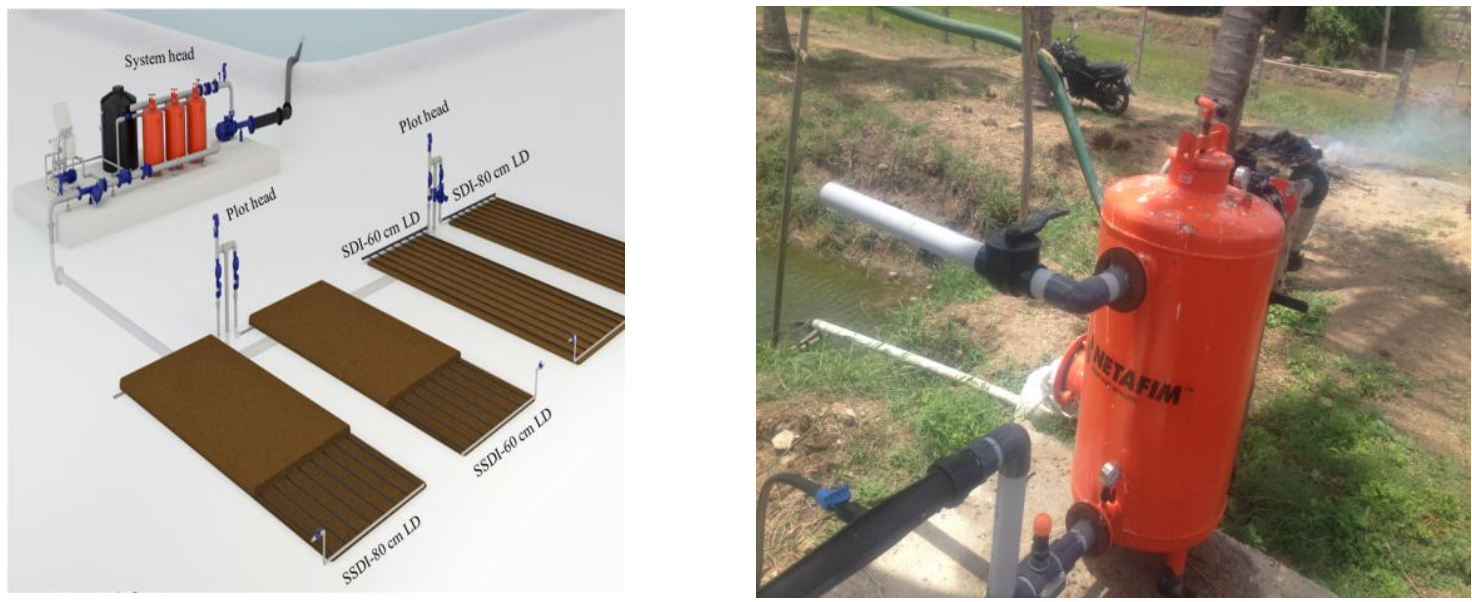

Fig.3 (a) Quantity of water applied as influenced by different cultivation practices, land levelling and irrigation methods for paddy production

- Irrigation water applied 2015 m Irrigation water applied 2016 Irrigation water applied Pooled

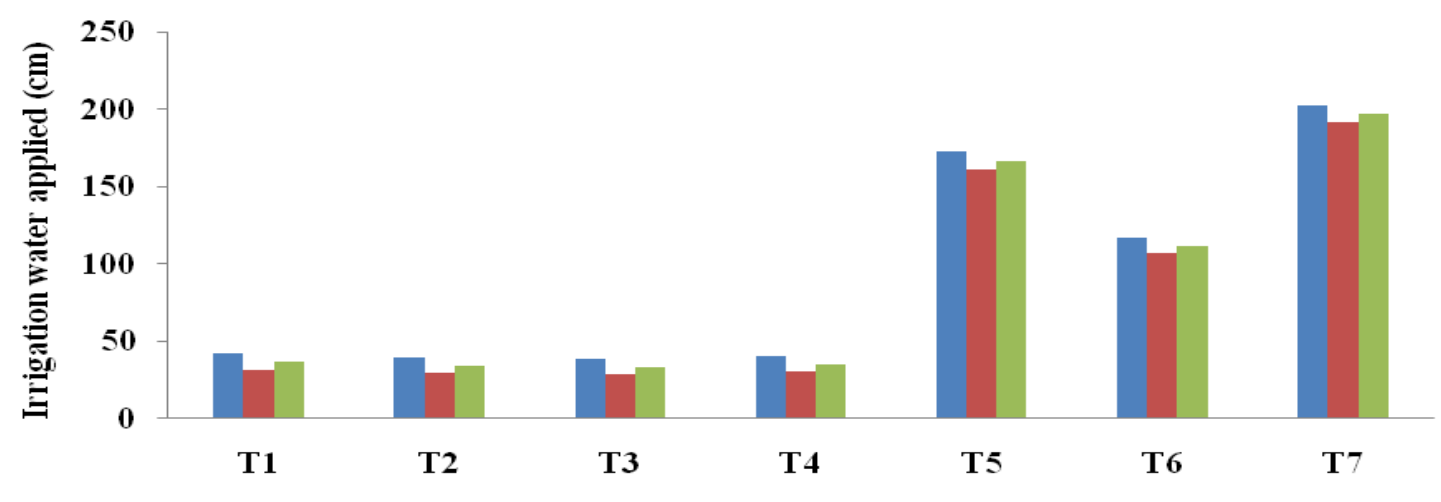


Fig.3 (b) Per cent saving as influenced by different cultivation practices, land levelling and irrigation methods for paddy production

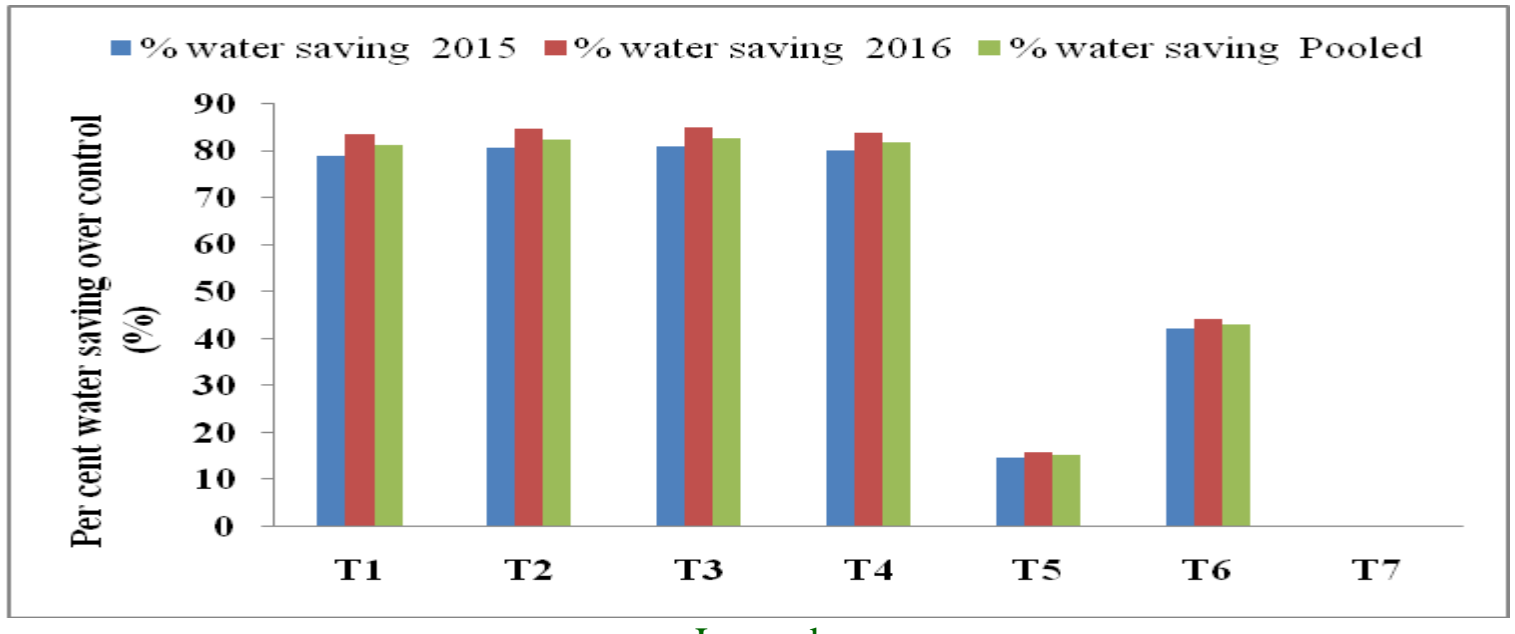

Legend

$\mathrm{T}_{1} \quad$ Dry Direct Seeded Rice (DSR) with Laser land levelling and Surface Drip irrigation (80 $\mathrm{cm}$ Lateral spacing)

$\mathrm{T}_{2} \quad$ Dry Direct Seeded Rice (DSR) with Laser land levelling and Surface Drip irrigation $(60 \mathrm{~cm}$ Lateral spacing)

$\mathrm{T}_{3} \quad$ Dry Direct Seeded Rice (DSR) with Laser land levelling and Sub-surface Drip irrigation $(60 \mathrm{~cm}$ Lateral spacing)

$\mathrm{T}_{4} \quad$ Dry Direct Seeded Rice (DSR) with Laser land levelling and Sub-surface Drip irrigation (80 cm Lateral spacing)

$\mathrm{T}_{5} \quad$ Transplanted Rice (TPR) with Laser land levelling and Conventional method of flood irrigation

$\mathrm{T}_{6} \quad$ Dry Direct Seeded Rice (DSR) with Conventional land levelling and Conventional method of flood irrigation

$\mathrm{T}_{7}$ Control (Conventional land levelling with Conventional method flood irrigation) i.e. Farmers' Practice

Among sown rice the highest per cent water saving was observed $\mathrm{T}_{3}(82.86 \%)$. It was followed by $\mathrm{T}_{2}(82.61 \%), \mathrm{T}_{4}(81.98 \%)$ and $\mathrm{T}_{1}(81.20 \%)$ when compared with control i.e. farmers' practice $\left(\mathrm{T}_{7}\right)$. The water saving was mainly due to precise levelling in laser levelled plots leading to smooth and faster movement of water thereby quick uniform distribution of water. Moreover, application of water to the root zone of crops by drip irrigation. But in control plot it was not so smooth. Whereas, water has to be applied so that the water reaches the high spots. The uniform distribution and reduced losses (Rajput and Patel, 2004, Abdullaev et al., 2007) in laser levelling plots also led to reduced depth of application and more saving of water. The irrigation time reduced considerably in laser levelled drip plots. The similar results on irrigation water requirement, depth and saving were obtained by Ahmad et al., (2001), Rickman (2002), Aggarwal et al., (2010), Shahin et al.,(2013) and Abdelraouf et al., (2014). Thus, laser land levelling and drip irrigation methods by saving considerable quantity of water were proved to be a RCTs in paddy production.

Laser land levelling and drip irrigation techniques used for paddy cultivation were observed to save huge quantity of irrigation water in paddy cultivation. The dry DSR plot with laser land levelling and subsurface drip irrigation at $60 \mathrm{~cm}$ lateral spacing required the lowest quantity of irrigation water whereas farmers' practice of growing paddy recorded the highest quantity of water usage of 19686 $\mathrm{m}^{3} \mathrm{ha}^{-1}$ in pooled mean. This was followed by plot with TPR with laser land levelling and conventional method of flood irrigation. The highest water saving (82.89 per cent) was observed in the plot with dry DSR with laser land levelling and sub-surface drip irrigation with $60 \mathrm{~cm}$ lateral spacing when compared with control i.e. farmers' practice. 


\section{Acknowledgements}

Authors express their gratitude to farmer Sri. Suresh Reddy who spared his land for drip irrigation studies in paddy. Authors also acknowledge the support of staff and Dean of College of Agricultural Engineering, UAS Raichur and CIMMYT New Delhi and Dean (PGS) of UAS Raichur for their help in successful completion of study.

\section{References}

Abdelraouf, R., Mehana, H. M., Sabreen, K. and Piparsand Bakry, 2014, Impact of laser land levelling on water productivity of wheat under deficit irrigation conditions. Current Res. Agric. Sci., 1(2): 53-64.

Abdullaev, I., Mehmood Ul Hassan and Kahramon Jumaboev, 2007, Water saving and economic impacts of land levelling: the case study of cotton production in Tajikistan. Irrig. Drain. Sys., 21:251-263.

Aggarwal, R., Samanpreetkaur and Amarjeet Singh, 2010, Assessment of saving in water resources through precision land levelling in Punjab. J. Soil Water Cons., 9(3): 182185.

Ahmad, B., Shahid, B. K. and Badar, H., 2001, Economics of laser land levelling in District Faisalabad, Pakistan J. Appl. Sci., 1(3): 409-412.

Anonymous, 2011, Ministry of Agriculture, Govt. of India. http:// www.indiastat.com.

Anonymous, 2016, Agricultural Statistics at a Glance. Agricultural Statistics Division, Directorate of Economics and Statistics. Department of Agriculture and Co- operation, Ministry of Agriculture, Government of India, New Delhi.

Jat, M. L., Pal, S. S., Subba Rao, A.V.M. and Sharma, S.K., 2003, Improving resource use efficiency in wheat through laser land levelling in an Ustochrept of Indo-gangetic plain. Paper presented In: Nation. Sem. on Dev. in Soil Sci., and $68^{\text {th }}$ Annu. Conv. of the Indian Soc. of Soil Sci., 4-8 November 2003, CSAUAT, Kanpur (UP).

Naresh, R. K., Singh, S. P., Misra, A. K., Tomar, S. S., Pardeep Kumar, Vineet Kumar and Sanjeev Kumar, 2014, Evaluation of the laser levelled land levelling technology on rice crop yield and water use productivity in Western Uttar Pradesh. Africa J. Agric. Res., 9(4):473-478.

Rajput, T. B. S., Patel, N. and Agarwal, G., 2004, Laser levelling- a tool to increase irrigation efficiency at field level. J. Agric. Engg., 41(1): 20-25.

Ramana Rao, K. V., 2013, Evaluation of drip irrigation system in paddy crop: A viable alternate to conventional water management practice in paddy cultivation CIAE, India. Paper presented In: Int. Exhibition and conf. on "Water Technologies, Environ. Technologies and Renewable Energy" 13-14, February, 2013, Bombay Exhibition Centre, Mumbai, India

Rickman, J. F., 2002, Manual for laser land levelling, Rice-wheat Consortium Tech. Bull. Series 5. New Delhi-12, India. Ricewheat consortium for the Indo-Gangetic Plains. pp. 24.

Shahin, A., Jafar, H. and Seyed, M. J. A., 2013, Levelling as a tool for reducing water casualties in wheat fields. Int. J. Agric. Crop Sci., 6(6): 296-299.

\section{How to cite this article:}

Ravindra Yaligar, P. Balakrishnan, U. Satishkumar, P. S. Kanannavar, A. S. Halepyati, M. L. Jat and Rajesh N. L. 2017. Water requirement of Paddy under Different Land Levelling, Cultivation Practices and Irrigation Methods. Int.J.Curr.Microbiol.App.Sci. 6(9): 3790-3796. doi: https://doi.org/10.20546/ijcmas.2017.609.468 